the link between the university and the weapons laboratory. Moreover, the decision could be implemented only with the approval of the federal government, approval which is unlikely to be forthcoming.

It is not only at Berkeley, however, that new debate is stirring on the relationship between scientific research and the development of nuclear weapons. At nearby Palo Alto, Stanford University students and faculty are waiting to hear whether the university will accept the first contract to carry out (unclassified) weapons related research at the Synchrotron Radiation Laboratory. More than 1,500 staff and students have signed a petition opposing any research explicitly dedicated to nuclear weapons development.

\section{Environmental pollution}

\section{Caribbean treaty promises much}

THE United Nations Environment Programme (UNEP) is claiming a modest success with the signature in March in Colombia of a convention for the protection of what is called the Wider Caribbean. The convention will become effective when it has been ratified by nine of the seventeen members of the conference at which it was drawn up, and in which both Cuba and the United States participated.

The origins of the treaty go back to 1976 , when UNEP and the Economic Commission for Latin America persuaded several Caribbean states to embark on a joint environmental project. The convention signed on 24 March at Cartagena de Indias is, like those in force in the Baltic and Mediterranean, permissive rather than prescriptive. But a protocol on the handling of oil spills has been added to the convention, while another on land-based sources of pollution is being drawn up.

How quickly the treaty will be followed by a substantial degree of technical cooperation will depend on who pays how much. UNEP boasts of an action plan for which pledges of $\$ 1.5$ million are being sought. Apart from the United States, Britain, France and the Netherlands are members of the convention, on which the European Community is also represented. But Brazil, perhaps over-sensitive about the effect on the Caribbean of the outflow of the Amazon, which is carried west by the Guiana and North Equatorial currents, is conspicuous by its absence.

Dr Arsenio Rodriguez, the Mexican marine biologist now working on the project from UNEP's Geneva office, says that to begin with attempts will be made to deal primarily with coastal problems. He considers that mangrove swamps may be more sensitive than other coastal vegetation to oil poliution, and that there is an urgent need to monitor the effects of run-off pesticides on tropical marine life. The Mississippi is the most obvious but not
The administration, meanwhile, is trying to encourage scientists to increase their involvement in weapons research. $\mathrm{Dr}$ George Keyworth, the president's science adviser, recently chided the research community for its lukewarm response to President Reagan's call for the invention of futuristic defence systems to safeguard against nuclear attack.

Even the science adviser, however, is not above a trace of doublethink on the question of whether scientists should become involved in the defence debate. The forthcoming issue of the journal of the American Physical Society will contain a letter from Dr Keyworth which criticizes the society's decision to endorse a nuclear freeze. Political activity, the letter is believed to assert, is not a proper function

Peter David

necessarily the most serious source of pollution, with the rapid and ill-regulated use of pesticides all round the Caribbean. There is also concern about the ease with which coral reefs - which mark the outer boundary of the wider Caribbean - may be killed, and about the disappearance of parrots and turtles from the islands.

UNEP hopes to increase its leverage by using the action fund to stimulate projects within a regional framework by national governments. Rodriguez hopes it will be possible to persuade member states to set up monitoring laboratories working to agreed standards of measurement, using a rehabilitated marine research laboratory on St Lucia as a model. Potential contributors to the trust fund have, however,

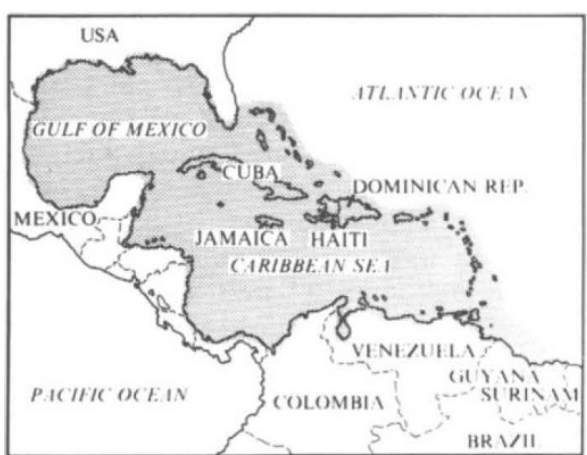

The Wider Caribbean Region, as defined by UNEP

apparently asked that nothing should be done to set up a coordinating unit in Jamaica until the work in hand is more than five times the cost of administration.

A good oil spill may be the best thing that could happen to the programme. The Ixtoc I blow-out in the Gulf of Mexico, which spilled an estimated 500,000 tonnes of oil in 1979, may indeed have spurred on the protocol on collaboration on oil spills. Now there is a prospect that the Caribbean could soon be producing 5 million barrels of oil a day. of a learned society.

\section{Biotechnology}

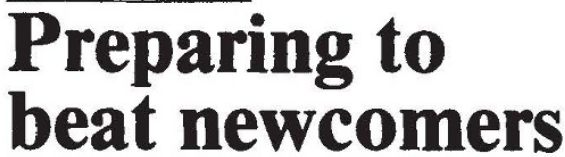

Fortia-Pharmacia, the Swedish-based international medical diagnostics and biotechnology company, plans to use the fat acquired during a successful 1982, when net income increased by 143 per cent, to expand research and development so as to shield itself against the small competitors springing up in the field of biotechnology.

Much of the increase of net income last year is attributable to the devaluation of the Swedish krona in October 1982. The annual report to the shareholders' meeting on 5 May shows that the group increased its net income from Skr131.2 million in 1981 to Skr318.3 million in 1982 $(£ 1=S k r 12.05)$. Sales rose by 29 per cent from Skr1,441 million to Skr 1,863 million, with pharmaceuticals accounting for 34 per cent of these and medical diagnostic products a further 23 per cent, but "separation products" such as chromatography kits, which made up 17 per cent of sales for 1982 , will be the centre of attention for 1983 . Strengthening its hold on the separation products market is intended to give FortiaPharmacia a substantial bite at the new biotechnology industry without taking it away from familiar ground and without exposing it to new competition.

As part of this strategy, FortiaPharmacia acquired three US companies during 1982 at a cost of some Skr111 million - P.L Biochemicals, the Milwaukee company specializing in fine chemicals for recombinant DNA techniques, Vespa Inc. (Pennsylvania), which manufactures raw materials for vaccines against insect allergies, and $\mathrm{Nu}$ Tech Medical Systems (Massachusetts), which produces catheters. The acquisitions were financed by the issue of shares in 1981 .

Interestingly, the 39 per cent increase in spending on research and development to Skr207 million, or 15 per cent of sales, in 1982 seems not to have been directed towards new fields but, more conservatively, to have been channelled into the development of existing techniques such as fast protein liquid chromatography. But the company seems to be looking to cooperative agreements, such as that reached last year with the University of Uppsala to invest Skr36 million in cell biology research over the next six years.

The public offering of stock in the United States in 1981 seems to have created unexpected problems for the company. It now says that it plans to be known uniformly as Pharmacia, while the report describes the complicated arrangements being made to make intelligible to investors elsewhere the Swedish taxation law that allows a company to accumulate financial reserves without paying tax until the money is used for some business purpose.

Melanie Kee 